\title{
Revitalization of Left Hands by Using Drill Method to Improve The Accuracy of Frisbee Throw Through to the Target
}

\author{
Arwinsyah $^{1}$, Tandiyo Rahayu ${ }^{2}$, Soegiyanto ${ }^{3}$, Setya Rahayu ${ }^{4}$ \\ ${ }^{1}$ Faculty of Mathematic and Natural Science, Universitas Sriwijaya, Indonesia \\ ${ }^{2,3,4}$ Graduate School Sport Education, Universitas Negeri Semarang, Indonesia \\ Corresponding email: winsyah2008@yahoo.co.id
}

\begin{abstract}
The purpose of this study is to analyze the training method of drill 1 and drill 2, endurance as well as male and female on the success of throwing frisbee to the target. The method of the study was quasi-experimental. The sample were 80 people consists of 40 elementary school students and 40 students of Binadarma University in Palembang. The sampling technique was purposive random sampling. The data were collected by experiment, data analysis by using Two-way analysis of variance (Anava). Multiple comparison tests by using Duncan test. The results show that the pretest of drill experiment is 33, posttest is 201 and g score is 168 , for control group, the pretest drill is 33, posttest 44 and $g$ score 11 . The results of drill test give effect on throw result, $(p=0.000728)$. Muscular endurance $(p=0.00000)$. Age $(p=0.00000)$. Gender $(p=0.00000)$. It is concluded that: There were an effect between drill 1 and drill 2, long and short muscle endurance to improve the accuracy of frisbee throw to the target. There was an influence between old and young ages, men and women to improve the accuracy of frisbee throw into the target.
\end{abstract}

Keyword: Left hand, Drill, Muscular endurance, Agr, Gender, Frisbee.

\section{Introduction}

Ninety percent of people in the world are right-handed (righties), on the other hand, the left-handed (lefties) are 9\% and every year, the number is increasing. The results of the comparison of ability analysis between the left and right hands of students in four elementary schools and four senior high schools prove that the ability of the left arm is lower than the right arm (Arwinsyah, 2009). Lefties want to adapt to the culture of righties because lefties must be able to be trained in repetitive ways, so when doing throws like javelin throw, discus throw, and frisbee, they can use both hands (ambidexterity).

Right-handed people/righties more use their right hand, so that their right hand has better skills. While, the left hand which is rarely used so it becomes less skilled, weaker and has smaller muscle size than the right hand. So it needs to be revitalized with a fun game that is to throw the frisbee backhand with the left hand in the target.

The result of the accuracy of frisbee throw to the target is an indicator of the success of left handed revitalization. The percentage of the use of both hands is still not much different. The game is the basic of the advance of physical education and sports. The fun frisbee game is one way to revitalize the left-hand of the student's righties.
Students need to revitalize their left hand of righties starting from the drill frisbee that is the exercise with a few sets and a lot of repetition. Repetition is the core of the exercise (Nala, 2005). Repetition exercises that are done over and over again will make the myelin nerve layer will become thicker and impulse transmission speed is accelerating. The myelin layer also makes saltatory conduction in the node of ranvier and causes brain neuroplasticity according to Brain Plasticity Theory (Davalos, 2005).

According to Mikheev (2001), the advantages of left-handed/lefties on sports which need quick reactions, appropriate spatial assessments and opposition. The examples of opposition sports are martial arts, racket game, bat, sword, stick, bat, and hockey. The advantage of the left hand on the double play sports is there will be no overlapping division of tasks. In the game sports like frisbee on the left wing, football on the left wing, volley on the left side, basketball on the left side and frisbee game on the left wing.

Left-handed drill training requires the support of dynamic muscular endurance, cyclical, and long-term. Dosage of muscular endurance training, dynamic, cyclical, long-term is maximum repetition, low set, low intensity, aerobic and continuously. Exercise throwing is by students do direct practice with a lot of repetition. 
According to Luciano (1990) to form working memory in which when it is repeated it becomes a short term memory. When it is repeated again, it will be long term memory and can be used when it is needed. It is because it has become a muscle memory in the motor cortex and (cerebellum) as well as myelinization of axons in the Central Nervous System/CNS \& Peripheral Nervous System/PNS. It occurs because of the neuroplasticity of the CNS. This throwing practice method requires dynamic muscular endurance, long-term and aerobic. The dosage of muscular endurance training is low intensity, high repetition and low set (Nala, 2005).

The selection of frisbee because on the backhand throw will cross the vertical plane of the body and will stimulate the right hemisphere function. Moreover, its advantages are: 1) Frisbee is not common, so there will be no "muscle memory", it prevents bias in the sample in Palembang 2) Frisbee types are varied, 3) Game type are varied, 4) Types of targets are varied, 5) Playground can be both inside and outside room, 6) The number of players are varied.

The purpose of this study is to analyze 1). The difference in the success of drill I (fixed set and repetition increases) and drill II (set increases and repetition remain) throws the frisbee into the target as the evidence of revitalization of the left hand improvement. 2). Analyze the successful gender differences of men and women in the throwing frisbee in the target as evidence of revitalization of the left hand improvement. The significance of the study is, it is expected to drill practice method can be used as one way to revitalize the left hand in the frisbee game.

\section{Methods}

The research was conducted in $S D$ Negeri 128/ State Elementary School 128 and Binadarma University of Palembang, the training program was three times a week and time allotment was 2X35 minutes. The population were 120 people, sample were 80 people (Left-handed people consisted of 40 male and 40 female left hand). The sample research procedures were as follows:

A. Individual Repetition Ability Test.

1) Ability test of One-repetition maximum. Participants threw the frisbee with their left hand as much as possible until they were guided, with a rhythm once in two seconds of a metronome recording. The data obtained by One-repetition maximum and the results were recorded.

2) The population was divided into two, namely population for method of drill I and drill II. The population of drill method I was the result of its One-repetition maximum divided by two. For example, test results Budi's repetition maximum was 100 times, it was divided by two then it was obtained 50 repetitions 2 sets. Group method of drill II, Bolang's repetition maximum test results were divided by five then it was obtained 20 repetition 5 sets.

3) The members of population of the drill I method with 100 replicates in which the implementation was 50 repetitions 2 sets. The members of population of drill II method was with 100 replicates which in its implementation was 20 repetitions 5 sets.

B. Test of Repetition Maximum Muscle Endurance Individual

1) After conducting stage $A$ of population of the drill method I and the drill II method of test of the Repetition Maximum Muscle Endurance by swinging the arm by holding the frisbee with a rhythm once in every 2 seconds.

2) Based on mean score of population of drill I and drill II, it was divided into two sample group, they were group of long muscle endurance and short muscle endurance

3) The long muscle endurance group was the one whose score is higher than the mean score, while the short muscle endurance was the one whose score lower than the mean score. Then it was conducted random pairing matching to determine the sampling of 40 people as a sample with long muscle endurance and it was chosen 40 people as a sample with short muscle endurance.

C. Age Group Test

1) Sampling from stage $B$ of 40 people by random pairing matching was divided into two age groups, children age ranging from 8-10 year-old and age 18-20 years-old.

2) The age sample of children was $8-10$ year old students of 20 people and sample of the age sample of teenager was $18-20$ year old students, there were 20 people

D. Gender Group Test

1) Samples taken from stage $C$ were 20 people with random pairing matching divided into two men and women 
2) The sample of male are 10 men and 10 women as a sample of female,

This research analyzed the effect of independent variable of drill method, muscle endurance, age, and gender. Meanwhile, dependent variable were the accuracy of frisbee throw with left hand. The research used two factorial $2 \times 2 \times 2 \times 2$ design. The treatment arranged by each individual can be the subject simultaneously of two different factors composed of several levels.

\section{Results and Discussion}

The test results score of the pre-test and post-test on the accuracy of frisbee throw can be seen in Figure 1 of experimental group.

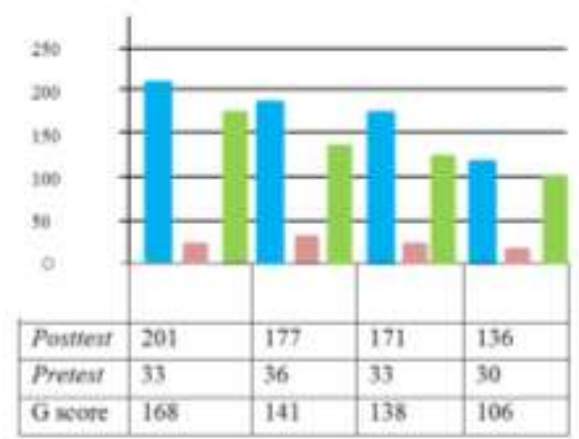

Figure 1 Frisbee's Exercise Throwing Test Result to the Target of the Experiment Group

Based on Figure 1, frisbee drill I, the long endurance increases by 168 . (The average of drill 1 from 33 to 201). Drill 1, the short endurance increases by 141. (The average drill I from 36 to 177). Drill II, the long endurance increases by 138. (The average drill II from 33 to 171). Drill II, short endurance increases by 106. (The average drill I from 30 to 136).

The test results score of the pre-test and post-test on accuracy of frisbee throw can be seen in Figure 2 of control group.

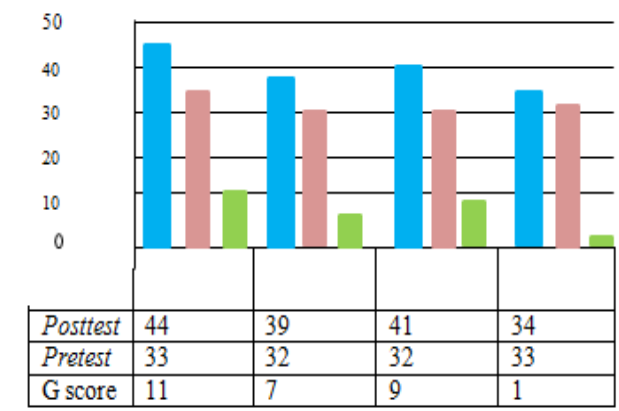

Figure 2 Frisbee's Exercise Throwing Test Result to the Target of the Control Group
Based on figure 2 shows that frisbee drill I (the long endurance) increases by 11. (The average of drill 1 from 33 to 44). Drill 1, the short endurance increases by 7 . (The average drill I from 32 to 39). Drill II, the long endurance increases by 9 . (The average drill I from 32 to 41). Drill II, short endurance increases by 1 . (The average drill I from 33 to 44).

Table 1 The Exercise Test Results of Drill Method, Endurance, Age, and Gender towards Frisbee throwing to Target with Left Hand.

\begin{tabular}{|c|c|c|c|c|c|}
\hline \multirow[t]{2}{*}{ Effect } & \multicolumn{5}{|c|}{$\begin{array}{c}\text { Univariate Results for Each DV Sigma- } \\
\text { restincted parameterization Effective } \\
\text { hypothesis decomposition }\end{array}$} \\
\hline & $\begin{array}{l}\text { Degree } \\
\text { of } \\
\text { Freedo } \\
\text { m }\end{array}$ & $\begin{array}{l}\text { The } \\
\text { number } \\
\text { of } \\
\text { throws } \\
\text { SS }\end{array}$ & $\begin{array}{l}\text { The } \\
\text { numb } \\
\text { er of } \\
\text { throw } \\
\text { s MS }\end{array}$ & $\begin{array}{l}\text { The } \\
\text { numb } \\
\text { er of } \\
\text { throw } \\
\text { s F }\end{array}$ & $\begin{array}{l}\text { The } \\
\text { numbe } \\
\mathrm{r} \quad \text { of } \\
\text { throws } \\
\mathrm{P}\end{array}$ \\
\hline Intercept & 1 & $\begin{array}{l}46985 . \\
42\end{array}$ & $\begin{array}{l}4698 \\
5.42\end{array}$ & $\begin{array}{l}7713 . \\
630\end{array}$ & 0.00 \\
\hline Drill & 1 & 69.77 & 69.77 & $\begin{array}{l}11.45 \\
4\end{array}$ & 0.00 \\
\hline Endurance & 1 & 279.08 & $\begin{array}{l}279.0 \\
8\end{array}$ & $\begin{array}{l}45.81 \\
6\end{array}$ & 0.00 \\
\hline Age & 1 & 662.70 & $\begin{array}{l}662.7 \\
0\end{array}$ & $\begin{array}{l}108.7 \\
96\end{array}$ & 0.00 \\
\hline Gender & 1 & 212.00 & $\begin{array}{l}212.0 \\
0\end{array}$ & $\begin{array}{l}34.80 \\
5\end{array}$ & 0.00 \\
\hline $\begin{array}{l}\text { Drill* } \\
\text { Endurance }\end{array}$ & 1 & 1.42 & 1.42 & 0.231 & 0.63 \\
\hline Drill* Age & 1 & 0.67 & 0.67 & 0.111 & 0.73 \\
\hline $\begin{array}{l}\text { Endurance } \\
* \text { Age }\end{array}$ & 1 & 2.27 & 2.27 & 0.372 & 0.54 \\
\hline $\begin{array}{l}\text { Drill*Gen } \\
\text { der }\end{array}$ & 1 & 3.50 & 3.50 & 0.575 & 0.44 \\
\hline $\begin{array}{l}\text { Endurance } \\
* \text { Gender }\end{array}$ & 1 & 9.63 & 9.63 & 1.582 & 0.20 \\
\hline $\begin{array}{l}\text { Age } \\
* \text { Gender }\end{array}$ & 1 & 23.41 & 23.41 & 3.843 & 0.05 \\
\hline $\begin{array}{l}\text { Drill* } \\
\text { Endurance } \\
* \text { Age }\end{array}$ & 1 & 9.92 & 9.92 & 1.628 & 0.20 \\
\hline $\begin{array}{l}\text { Drill* } \\
\text { Endurance } \\
* \text { Gender }\end{array}$ & 1 & 22.53 & 22.53 & 3.699 & 0.05 \\
\hline $\begin{array}{l}\text { Drill* Age } \\
* \text { Gender }\end{array}$ & 1 & 17.63 & 17.63 & 2.895 & 0.06 \\
\hline $\begin{array}{l}\text { Endurance } \\
* \quad \text { Age }\end{array}$ & 1 & 36.85 & 36.85 & 6.050 & 0.01 \\
\hline $\begin{array}{l}\text { *Gender } \\
\text { Drill* } \\
\text { Endurance } \\
* \quad \text { Age }\end{array}$ & 1 & 1.52 & 1.52 & 0.249 & 0.06 \\
\hline $\begin{array}{l}\text { *Gender } \\
\text { Error }\end{array}$ & 1904 & $\begin{array}{l}11597 . \\
68\end{array}$ & 6.09 & & \\
\hline Total & 1919 & $\begin{array}{l}12950 . \\
58\end{array}$ & & & \\
\hline
\end{tabular}


Multiple comparison test analysis with Duncan test shows that there is a difference between drill method I and II on the accuracy of throwing frisbee with left hand on Binadarma university students and 128 elementary students in Palembang. The drill 1 and II methods affect the result of the throwing, with $(p=0.000728)$. (Candiasa, 2010).

The Duncan Test results show that drill 1 and drill 2 both have a significant effect on the accuracy of frisbee the into the target, with an average score, drill 1 of 5.137500 and the average drill 2 of 4.756250 . Result of comparative test between long and short arm muscle endurance towards the accuracy of frisbee throw with left hand of university students and elementary school 128 students in Palembang. It gives effect on the accuracy of frisbee throw to the target $\mathrm{p}=0,00$.

The effect of short and long endurance is different. Duncan Test results show that both short and long endurance has a significant effect on the accuracy frisbee throw to the target, with an average of long endurance of 5.328125 and the average of short endurance of 4.45 .

Result of comparative test between 8-10 year-old and 18-20 year-old on the accuracy frisbee throw with left hand of Binadarma university students and elementary school 128 students in Palembang. It gives effect on throw result $(p=0,089025)$. Duncan test results show that both old and young age have the effect on the accuracy of frisbee throw into the target, with an averageof old age of 5.534375 and an average of young age of 4.359375 .

Result of comparative test between men and women on the accuracy of frisbee throw with left hand on Binadarma university students and elementary school 128 students in Palembang. It gives effect on the accuracy of frisbee throw with the left hand $(\mathrm{p}=0.013994)$. The given effect of men and women are different. Duncan test results show that both men and women have a real effect on the accuracy of Frisbee throw to the Target, with an average of drill of 1 of 5.279167 and the average of drill 2 of 4.614583.

The efforts to overcome the weakness of this method are 1 . It is only used to train motoric skills. 2. Before implementing this method, students should be given an understanding of what will be trained and benefits for themselves. 3. The first application is diagnostic. If in the first exercise, students fail, then the teachers must make improvements, then refinement. 4.
Exercise should be interesting and fun. 5. The characteristics of the exercise in the first stage is accuracy and speed, Ramayulis (2005). After training, students must learn to imagine and repeat the successful frisbee throw in their memory and they do not allowed to buy frisbee or frisbee exercise outside the day and practice hours.

It is explained in the attractiveness of frisbee plate because it has aerodynamic characteristics in accordance with Bernoulli's principle. When it is thrown, plates drift in the air, so the plates are relatively easy to throw, caught and manipulated. The law of flying saucer physics is the resulting lift equal to the traditional asymmetrical airfoil that is by accelerating the flow of air above the hollow so that the airflow pressure difference generates lift.

The front bulge serves as turbulators, reducing the flow separation by forcing airflow to become turbulent after passing the bulge. Rotating plates have has a vertical corner momentum vector, stabilizing gyroscopically. Depending on the cross-sectional shape of the airfoil amount of lift generated by the front and the back of the plate, it may be different. If the plate does not spin it will tend to fall.

Drill method is a way of teaching by giving training to what has been learned by the students, hence, they get a certain skill. The word drill means something that is repeated (Ramayulis, 2005). Without drill and good technique, the accuracy of the player in throwing will look poor in inserting frisbee into the target.

\section{Conclusion}

The drill I method is more effective than the drill II method in improving the accuracy of frisbee throw to the target, however, both methods have a significant effect on the accuracy of frisbee throw to the target. Male is better than female in improving the accuracy of frisbee throw to the target, both of them an effect on the accuracy of frisbee throw to the target.

\section{References}

Arwinsyah, 2009. Bahasa Tubuh di Tinjau Dari Bioantropologi dan Al Quran. Majalah Al Ghazali. Palembang: Univeristas Sriwijaya Press.

Davalos, D.G., 2005. ATP Mediateds Rapid Microglial Response to Local Brain Injury in Vivo. Nature Neuroscience, 8: 752. 
Gaser, 2003. Brain Structures Differ Between Musicians and Musicians. Jounal of Neuroscience. 23: 92.

Ivry, R.B., 2000. Impaired Velocity Perception In Patients With Lessons Of The Cerebellum. Journal of Cognitive Neuroscience. 3: 29

Jacobs, 1993. A Quantitative Dendritic Analysis of Wernicke's Area In Humans: Lifespans Change. Jurnal of Comparative Neurology. 327: 90.

Luciano, 1990. Human Physiology. New York: McGraw-Hill Publishing Company
Mikheev, 2001. Motor Control and Cerebral Hemispheric Specialization in Highly Qualified Judo Wrestlers. Neuropsychologia. 40: 2-6.

Nala, 2005. Prinsip Pelatihan Fisik Olahraga. Monograf yang Diperbanyak Oleh Program Studi Fisiologi Olahraga. Program Pascasarjana Univeristas Udayana..

Ramayulis, 2005. Metodologi Pendidikan Agama Islam. Jakarta: Penerbit Kalam Mulia. 